\title{
Integration of the Technology Readiness and Adoption Models for Assessing IT Use among SMEs in Indonesia
}

\author{
Asrul Sani ${ }^{1}$, A’ang Subiyakto $^{2}$, T.K.A.Rahman ${ }^{3}$ \\ ${ }^{1}$ STMIK Widuri Jakarta, Indonesia \\ ${ }^{2}$ Syarif Hidayatullah State Islamic University Jakarta, Indonesia \\ ${ }^{3}$ Asia e University Selangor, Malaysia \\ asrulsani@kampuswiduri.ac.id, aang_subiyakto@uinjkt.ac.id, titik.khawa@aeu.edu.my
}

Keywords: $\quad$ Readiness, Adoption, SMEs, Model development, Indonesia

\begin{abstract}
In developing a company, the interaction between the customer and the company is very important in relation to the development of a company. The use of technology-based systems is certainly very much needed and service to customers. In this case, the company must improve technology-based system services so that customers can easily obtain information or other knowledge from the company. Building technology-based systems require the readiness to operate, develop and improve technology. This article will begin with how to develop the technology readiness of an SME company so that it can undergo the activities of the company well, and will end with a practical discussion whether the application of IT technology in SME companies require deeper development or just simply there. The aim of the research is to deepen our understanding of the role of technology in its use in SME companies in terms of marketing and serving customers.
\end{abstract}

\section{INTRODUCTION}

To be able to survive in the development of the company, in this case, new economies, belonging SMEs, are encouraged to adopt a technology development. Businesses that do not adopt the philosophy and practice the application of information technology will be left behind by users. Furthermore, stated by Jerry Jesionowski, President of the US National Producers Association, in the wall street journal that small companies need to enter into the application of IT technology or they will be closed from an important part of the market (Shah Alam et al., 2011).

For the success and improvement of a country's economy and social development, entrepreneurship plays a major role that contributes to economic improvement. Entrepreneurial activity is a precondition for the success of economic growth, development, job creation, social welfare and political stability(Eggers et al., 2013, Filser and Eggers, 2014).

The development of small and medium enterprises (SMEs) is very important in developing countries for the role of society in terms of economic improvement; improving the distribution of income and sales, productivity, efficiency and structure and economic foundations during the economic downturn (Abdullah et al., 2011). In this case Indonesia, the role of entrepreneurship is very important to make Indonesia become a developing country (Nugroho, 2015).

Along with increasing universal competitiveness in the market and economic region, it is now SMEs must develop themselves in order to have and have strong competition. SME business development has been well developed and highly regarded by the Government of the Republic of Indonesia as stated in the Long-term Development Plan (RPJP) 2005 - 2025, as a contribution to the greater economic development and competitive spirit . To achieve this, it is very important to reinforce and develop SMEs, and one of its development strategies is through the application and development of innovations and the utilization of technology. At the application level of technology, especially the application of information technology is very low, which is about 30 to $40 \%$ (2011).

Implementation the application of information technology can be intended as the use of technology-based systems to monitor information at all levels of organizations and business. The positive influence utilization of information technology applications for SMEs is a valuable 
performance improvement in the marketing division, communication, and network division, as well as on the planning division of resources, so as to improve financial management and all of operation achievement if information technology can be utilized properly (Fathian et al., 2008). From the results of the research that will be carried out and already mentioned, there will be two questions that will be given to guide the implementation of research on the exploration of this research namely.

Q1: How to understand the connection between technology readiness and technology adoption constructs?

Q2: How to develop the technology readiness and technology adoption models in terms of IT use among SMEs in Indonesia?

This paper is divided into five parts. The first part will explain the research is research program. Then followed by a literature review, research method, results and discussion, and conclusions in the second, third, fourth, and fifth sections respectively

\section{LITERATURE REVIEW}

A preliminary studies that have been done by Parasuraman (Parasuraman, 2000), was a study that explains how the level of readiness of users to the implementation of technology in an organization. Users are the level of maturity of a person who must have knowledge of information technology so it is easy to digest the application system that will be implemented. At the same time, the utility of a technology is the ultimate goal of the user to master the information communication and technology (A. Parasuraman 2014).

Parasuraman and Colby explain technological readiness as a tendency for people to get together and use new technologies to achieve goals at home and at work, TRI (Technology Readiness Index) developed by Parasuraman to measure a person's beliefs and thoughts in general about the application of technology. Someone thinking about the application of technology can be more positive right, that was optimism in speaking of application technology and also a tendency to gain discomfort and skepticism over the application of technology. That's why there are four dimensions in technology readiness: optimism, innovation, discomfort, and insecurity arise (Parasuraman and Colby, 2015, Parasuraman, 2000).

The first two measure of readiness technology are optimism and innovation benefactor that can update the readiness towards the use of technology, while for the rest that is discomfort and insecurity are considered as an inhibitor that can suppress the degree of readiness technology (Colby, 2016).

Parasuraman and Colby stressing that the readiness of applying a technology is a measurement tool to provide perceptions or thoughts about the use of technology, not as a measure of one's ability or capacity to use technology. Based on the level of technology application readiness scores, users are classified into five sections: explorer, pioneer, skeptic, paranoids, and sluggish. Cruiser type has the top score in the benefactor dimension (optimism, innovative) and low score in the dimension of the inhibitor (discomfort, insecurity) (Parasuraman and Colby, 2015).

Explorers are easily enamored to new technology and become the first group to try it out. Meanwhile, on the other side, sluggish is the last group type to adopt new technology and has the top score on the dimensions of the inhibitor and the low score on the benefactor dimension. Meanwhile, three things another is pioneers, skeptics, paranoids have a more complex assumption of technology. Pioneers have high optimism and innovation like exploration, but at the same time, they can be easy stop using if they get any discomfort (Parasuraman and Colby, 2015, A. Parasuraman 2014).

Sceptics have low encouragement to use technology but they have too low obstacle rates so they need to be convinced about the utility of technology. Study on Parasuraman and Colby show that explorers and pioneer types incline to use new technologies earlier than others, the paranoid, technology is indeed interesting but they also take into consideration the risks factor, this indicated by a high level of discomfort (RojasMéndez et al., 2017).

Lucchetti and Sterlacchini who have studied several cases of SMEs that occurred in Italy and they found that attitude towards the adoption of Information and Communication Technology (ICT). The results of their research revealed that effective adoption and use of ICT was differentiated, depending on internal funds and technological skills the company that has been done and utilized, on the one hand, and the nature of the business, on the other (Lucchetti and Sterlacchini, 2004)

Harindranath et al. also found and tried to explain the reasons for the low use of ICT by UK 
SMEs. According to their findings, one of the main concerns of UK managers was the fear of limited use and obsolescence of an IT that will, moreover, require frequent updates. This happens because the unpreparedness of the user and the technology that will be used is an important problem in SMEs (Harindranath et al., 2008)

\section{RESEARCH METHODS}

The study of model development was conducted into four main stages (Fig. 1). First, the preliminary study (1) was carried out by conducting initial preparations, namely the study of literature and preparing the model to be developed including looking at the type of organization, and social aspects of the IS study, for example, usefulness, satisfaction, and readiness (Shah Alam et al., 2011, Eggers et al., 2013, Nugroho, 2015, Parasuraman, 2000, A. Parasuraman 2014, Rojas-Méndez et al., 2017). In addition to reviewing the literature, it was also carried out to formulate the research program to be conducted.

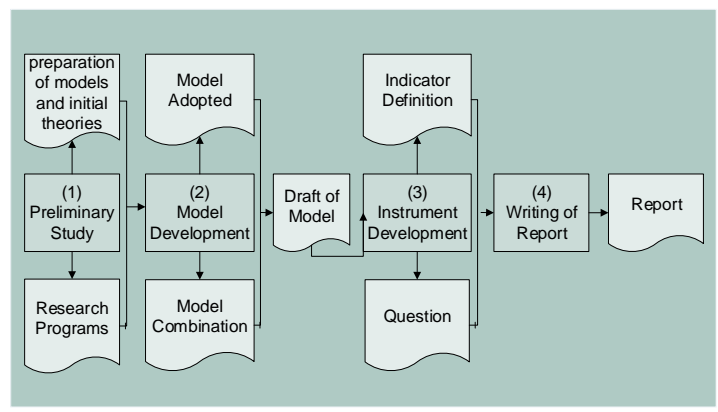

Figure 1: Research procedure

Then the second stage was modeling by adopting and combining the models that have been developed (2) which produce a draft model.

Third, the results of the draft model, then produce instrument development. At this stage, the researchers define indicators in their development, and then develop questions from each item measurement considering the study context.

Finally, the implementation of research instrument development was then reported. As explained in this paper, the design of the proposed model consists of two main parts, namely the selfdeveloped model and the question list question (Table 1).
Table 1: List of the models and theories

\begin{tabular}{|c|c|}
\hline The Models and Theories & References \\
\hline $\begin{array}{c}\text { Theory of information } \\
\text { processing }\end{array}$ & (Davis and Yen, 1998) \\
\hline $\begin{array}{c}\text { Readiness model } \\
\text { technology }\end{array}$ & $\begin{array}{c}\text { (Parasuraman and } \\
\text { Colby, 2015, } \\
\text { Parasuraman, 2000, A. } \\
\text { Parasuraman 2014, } \\
\text { Rojas-Méndez et al., } \\
\text { 2017) }\end{array}$ \\
\hline $\begin{array}{c}\text { Professional and casual } \\
\text { models of a model } \\
\text { development }\end{array}$ & $\begin{array}{c}\text { (Hanclova et al., 2015, } \\
\text { Gangwar et al., 2014) }\end{array}$ \\
\hline & $\begin{array}{c}\text { 2014, Subiyakto and Ahlan, 2017, } \\
\text { Subiyakto et al., 2015) }\end{array}$ \\
\hline
\end{tabular}

Following the assumptions developed, Parasuraman and Colby's technology readiness model (Parasuraman and Colby, 2015) was later adopted, combined, and adapted in the second stage (2). A draft model was obtained which was then developed at the level of research instruments in the operational phase (3). Finally, the research model developed and the data collection instruments are then proposed in the reporting phase, in terms of conducting research.

\section{RESULT AND DISCUSSION}

The resulting model is a combination of the Parasuraman readiness model (Parasuraman and Colby, 2015), the Chatzoglou adoption model (Chatzoglou and Chatzoudes, 2016) and Zhu et al (Zhu et al., 2006) . Figure 2 shows the proposed model with eleven variables and 30 relational hypotheses.

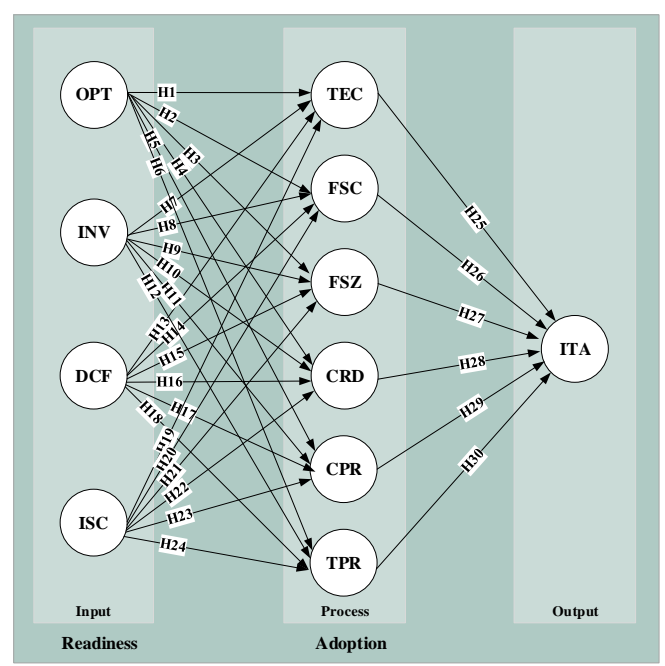

Figure 2: The Proposed model 
Readiness, adoption, and adjustment of both models are carried out based on input process output logic (IPO) theory of information processing (Anfara Jr and Mertz, 2014) and process logic and causal concepts of development model (Belout and Gauvreau, 2004). The authors hypothesize that technology readiness model variables (Parasuraman and Colby, 2015) (i.e., [OPT] Optimism, [INV] innovation, discomfort [DCF], and insecurity [ISC]) influence adoption in Chatzoglou SMEs (Chatzoglou and Chatzoudes, 2016) and Zhu et al. (Zhu et al., 2006) (i.e., Technology Competence [TEC ], Firm Scope [FSC], Firm Size [FSZ], Customer Readiness [CRD], Competitive Pressure [CPR], Lack of Trading Partner Readiness (TPR), and IT Adoption [ITA]).

The level of an organization's technology is an important element that can influence the adoption model and implementation of IS / IT innovation. According to Zhu et al. (Zhu et al., 2006) the level of a technology is strongly influenced by technological competencies and employee technical skills and suggested that technology competencies, firm scope, firm size, consumer readiness, competitive pressure and lack of readiness trading partners used to assess IT Usage among SMEs in Indonesia.

Table 2: List of the variables (Chatzoglou and Chatzoudes, 2016, Parasuraman and Colby, 2015, Zhu et al., 2006)

\begin{tabular}{|c|l|l|}
\hline Codes & Names & \multicolumn{1}{|c|}{ Definitions } \\
\hline OPT & Optimism & $\begin{array}{l}\text { The level of confidence } \\
\text { in believing that } \\
\text { technology adoption } \\
\text { might occur. }\end{array}$ \\
\hline INV & Innovation & $\begin{array}{l}\text { The level of confidence } \\
\text { of seeing that adoption } \\
\text { technology is part of a } \\
\text { system. }\end{array}$ \\
\hline DCF & Discomfort & $\begin{array}{l}\text { The level of confidence } \\
\text { in knowing that } \\
\text { technology is } \\
\text { uncomfortable. }\end{array}$ \\
\hline ISC & Insecurity & $\begin{array}{l}\text { The level of confidence } \\
\text { of distrust that } \\
\text { technology adoption } \\
\text { can be properly } \\
\text { implemented and } \\
\text { concerns about } \\
\text { potentially harmful } \\
\text { consequences }\end{array}$ \\
\hline
\end{tabular}

\begin{tabular}{|c|c|c|}
\hline Codes & Names & Definitions \\
\hline TEC & $\begin{array}{l}\text { Technology } \\
\text { Competence }\end{array}$ & $\begin{array}{l}\text { The level of confidence } \\
\text { of technologies } \\
\text { (hardware) that enable } \\
\text { an organization to } \\
\text { develop processes }\end{array}$ \\
\hline FSC & Firm Scope & $\begin{array}{l}\text { The level of confidence } \\
\text { of horizontal expansion } \\
\text { of an enterprise's } \\
\text { operations }\end{array}$ \\
\hline FSZ & Firm Size & $\begin{array}{l}\text { The level confidence of } \\
\text { which to a larger } \\
\text { company may have a } \\
\text { competitive advantage } \\
\text { over its smaller } \\
\text { counterparts }\end{array}$ \\
\hline CRD & $\begin{array}{l}\text { Customer } \\
\text { Readiness }\end{array}$ & $\begin{array}{l}\text { The level of confidence } \\
\text { of a combination of } \\
\text { consumer willingness } \\
\text { and Internet penetration }\end{array}$ \\
\hline CPR & $\begin{array}{l}\text { Competitive } \\
\text { Pressure }\end{array}$ & $\begin{array}{l}\text { The level of confidence } \\
\text { to affect the industry } \\
\text { structure, and leverage } \\
\text { new ways to } \\
\text { outperform rivals, thus } \\
\text { changing the } \\
\text { competitive } \\
\text { environment }\end{array}$ \\
\hline TPR & $\begin{array}{c}\text { Lack of Trading } \\
\text { Partner Readiness }\end{array}$ & $\begin{array}{l}\text { The level confidence of } \\
\text { status of its trading } \\
\text { partners along the value } \\
\text { chain, since for an } \\
\text { electronic trade to take } \\
\text { place, it is necessary } \\
\text { that all trading partners } \\
\text { adopt compatible } \\
\text { electronic trading } \\
\text { systems }\end{array}$ \\
\hline ITA & IT Adoption & $\begin{array}{l}\text { The level of confidence } \\
\text { to which a company } \\
\text { adopts a technology for } \\
\text { the development of its } \\
\text { industry }\end{array}$ \\
\hline
\end{tabular}

Table 3: List of the indicators (Chatzoglou and Chatzoudes, 2016, Parasuraman and Colby, 2015, Zhu et al., 2006)

\begin{tabular}{|l|l|l|}
\hline Codes & Names & \multicolumn{1}{|c|}{ Definitions } \\
\hline OPT1 & Easiness & $\begin{array}{l}\text { The level connected to } \\
\text { system achievement to } \\
\text { get freedom from } \\
\text { obstacles, difficulties, } \\
\text { and problems }\end{array}$ \\
\hline
\end{tabular}




\begin{tabular}{|c|c|c|}
\hline Codes & Names & Definitions \\
\hline OPT2 & Connectivity & $\begin{array}{l}\text { The level connected to } \\
\text { the system achievement } \\
\text { so that it is connected } \\
\text { successfully with the } \\
\text { existing system }\end{array}$ \\
\hline OPT3 & Efficiency & $\begin{array}{l}\text { The level connected to } \\
\text { the system achievement } \\
\text { to get output with } \\
\text { comparison of the } \\
\text { resources needed to } \\
\text { achieve output }\end{array}$ \\
\hline OPT4 & Effectiveness & $\begin{array}{l}\text { The level connected to } \\
\text { the ability of the system } \\
\text { to reach its utilization } \\
\text { targets }\end{array}$ \\
\hline OPT5 & Productivity & $\begin{array}{l}\text { The level connected to } \\
\text { the system support to } \\
\text { produce output } \\
\text { compared to the } \\
\text { revenue needed to } \\
\text { producing output }\end{array}$ \\
\hline INV1 & Solve Problem & $\begin{array}{l}\text { The level connected to } \\
\text { the system support for } \\
\text { make solutions to } \\
\text { subject }\end{array}$ \\
\hline INV2 & Independency & $\begin{array}{l}\text { The level connected to } \\
\text { the system able to } \\
\text { support user free from } \\
\text { the influences }\end{array}$ \\
\hline INV3 & Challenges & $\begin{array}{l}\text { The level connected to } \\
\text { the system support to } \\
\text { successfully repair or } \\
\text { get things in difficult } \\
\text { situations or conditions }\end{array}$ \\
\hline INV4 & Stimulation & $\begin{array}{l}\text { The level connected to } \\
\text { the system support to } \\
\text { reach something that is } \\
\text { and is developing, or } \\
\text { enhanced }\end{array}$ \\
\hline INV5 & $\begin{array}{l}\text { Strength of } \\
\text { Competition }\end{array}$ & $\begin{array}{l}\text { The level connected to } \\
\text { the system capabilities } \\
\text { to support users so that } \\
\text { they can be more } \\
\text { successful than their } \\
\text { competitors }\end{array}$ \\
\hline DCF1 & Complication & $\begin{array}{l}\text { The level connected to } \\
\text { the system view that is } \\
\text { confusing and difficult } \\
\text { to understand and } \\
\text { modify }\end{array}$ \\
\hline DCF2 & Difficulty & $\begin{array}{l}\text { The level connected to } \\
\text { the system conditions } \\
\text { that cannot be easily } \\
\text { operated or used }\end{array}$ \\
\hline
\end{tabular}

\begin{tabular}{|c|c|c|}
\hline Codes & Names & Definitions \\
\hline DCF3 & Dependence & $\begin{array}{l}\text { The level connected to } \\
\text { the system conditions } \\
\text { that require other } \\
\text { parties to run the } \\
\text { system }\end{array}$ \\
\hline DCF4 & Lack of Support & $\begin{array}{l}\text { The level connected to } \\
\text { a system that has no } \\
\text { source, or is sufficient, } \\
\text { from the needs in its } \\
\text { operation }\end{array}$ \\
\hline DCF5 & Incompatibility & $\begin{array}{l}\text { The level connected to } \\
\text { the circumstances } \\
\text { where there is a } \\
\text { discrepancy }\end{array}$ \\
\hline ISC1 & Failure & $\begin{array}{l}\text { The level connected to } \\
\text { the circumstances } \\
\text { where unpleasant or } \\
\text { dangerous systems can } \\
\text { occur }\end{array}$ \\
\hline ISC2 & Threat & $\begin{array}{l}\text { The level connected to } \\
\text { the system situation that } \\
\text { could cause harm or } \\
\text { danger }\end{array}$ \\
\hline ISC3 & $\begin{array}{l}\text { Reducing } \\
\text { Interaction }\end{array}$ & $\begin{array}{l}\text { The level connected to } \\
\text { the application of a } \\
\text { system that makes } \\
\text { human relations less in } \\
\text { size, quantity, and } \\
\text { interest }\end{array}$ \\
\hline ISC4 & Distraction & $\begin{array}{l}\text { The level connected to } \\
\text { use the system to get } \\
\text { attention and avoid } \\
\text { people thinking about } \\
\text { something else }\end{array}$ \\
\hline ISC5 & Incredulity & $\begin{array}{l}\text { The level connected the } \\
\text { system is doubtful of its } \\
\text { use }\end{array}$ \\
\hline TEC1 & Technologies & $\begin{array}{l}\text { The level connected to } \\
\text { hardware and software } \\
\text { devices in carrying out } \\
\text { work processes so that } \\
\text { it is easy to implement }\end{array}$ \\
\hline TEC2 & Internet & $\begin{array}{l}\text { The level connected to } \\
\text { this type of work in the } \\
\text { context of the use of } \\
\text { technology }\end{array}$ \\
\hline TEC3 & Intranet & $\begin{array}{l}\text { The level connected to } \\
\text { the relationship } \\
\text { between users and other } \\
\text { users in a work } \\
\text { environment }\end{array}$ \\
\hline TEC4 & E-mail & $\begin{array}{l}\text { The level connected to } \\
\text { correspondence using } \\
\text { electronic mail so that it } \\
\text { is easy to reach }\end{array}$ \\
\hline
\end{tabular}




\begin{tabular}{|c|c|c|}
\hline Codes & Names & Definitions \\
\hline TEC5 & Tools & $\begin{array}{l}\text { The level connected to } \\
\text { use of the device so that } \\
\text { it is easy to connect to } \\
\text { each other and easy to } \\
\text { use }\end{array}$ \\
\hline FSC1 & Reaches & $\begin{array}{l}\text { The level connected to } \\
\text { business reach that can } \\
\text { be achieved in terms of } \\
\text { marketing }\end{array}$ \\
\hline FSC2 & Variation & $\begin{array}{l}\text { The level connected to } \\
\text { types of work that can } \\
\text { be done according to } \\
\text { capacity }\end{array}$ \\
\hline FSC3 & Establishment & $\begin{array}{l}\text { The level connected to } \\
\text { Strengths and } \\
\text { weaknesses of the firm } \\
\text { being developed }\end{array}$ \\
\hline FSC4 & Operationalization & $\begin{array}{l}\text { The level connected to } \\
\text { ongoing production } \\
\text { activities }\end{array}$ \\
\hline FSC5 & Geographic's & $\begin{array}{l}\text { The level connected to } \\
\text { the state of the work } \\
\text { atmosphere in the } \\
\text { process activity }\end{array}$ \\
\hline FSZ1 & Data & $\begin{array}{l}\text { The level connected to } \\
\text { seeing the amount of } \\
\text { data used based on the } \\
\text { size of the firm }\end{array}$ \\
\hline FSZ2 & Clustering & $\begin{array}{l}\text { The level connected of } \\
\text { a small group of people } \\
\text { or things that are very } \\
\text { close to each other }\end{array}$ \\
\hline FSZ3 & Employees & $\begin{array}{l}\text { The level connected to } \\
\text { a number of employees } \\
\text { used }\end{array}$ \\
\hline FSZ4 & Classified & $\begin{array}{l}\text { The level connected to } \\
\text { a category of industrial } \\
\text { types produced by } \\
\text { looking at the } \\
\text { magnitude of activity }\end{array}$ \\
\hline FSZ5 & Model & $\begin{array}{l}\text { The level connected to } \\
\text { a model used in the } \\
\text { firm is adjusted to the } \\
\text { number of employees }\end{array}$ \\
\hline CRD1 & Strategic & $\begin{array}{l}\text { The level connected to } \\
\text { carefully planned to get } \\
\text { the desired results }\end{array}$ \\
\hline CRD2 & Consumer & $\begin{array}{l}\text { The level connected to } \\
\text { someone who buys and } \\
\text { uses goods and services }\end{array}$ \\
\hline CRD3 & Penetration & $\begin{array}{l}\text { The level connected to } \\
\text { companies or teams are } \\
\text { against each other } \\
\text { before entering the } \\
\text { computer era }\end{array}$ \\
\hline
\end{tabular}

\begin{tabular}{|c|c|c|}
\hline Codes & Names & Definitions \\
\hline CRD4 & Industry & $\begin{array}{l}\text { The level connected to } \\
\text { people and } \\
\text { organizations involved } \\
\text { in producing goods }\end{array}$ \\
\hline CRD5 & Driver & $\begin{array}{l}\text { The level connected to } \\
\text { something that makes } \\
\text { important things } \\
\text { happen, for example in } \\
\text { an organization or } \\
\text { economy }\end{array}$ \\
\hline CPR1 & Competitive & $\begin{array}{l}\text { The level connected to } \\
\text { companies or teams are } \\
\text { against each other }\end{array}$ \\
\hline CPR2 & Pressure & $\begin{array}{l}\text { The level connected to } \\
\text { attempts to persuade, } \\
\text { thread, or force } \\
\text { someone to do } \\
\text { something }\end{array}$ \\
\hline CPR3 & Structure & $\begin{array}{l}\text { The level connected to } \\
\text { a company's strengths } \\
\text { in dealing with the } \\
\text { times }\end{array}$ \\
\hline CPR4 & Analysis & $\begin{array}{l}\text { The level connected to } \\
\text { the process of studying } \\
\text { or examining something } \\
\text { in detail in order to } \\
\text { understand it or explain } \\
\text { it }\end{array}$ \\
\hline CPR5 & Integration & $\begin{array}{l}\text { The process of } \\
\text { becoming involved } \\
\text { completely in its } \\
\text { activities }\end{array}$ \\
\hline TPR1 & Beyond & $\begin{array}{l}\text { The level connected to } \\
\text { a company must have a } \\
\text { far-sighted thinking to } \\
\text { build together }\end{array}$ \\
\hline TPR2 & Supply Chain & $\begin{array}{l}\text { The level connected to } \\
\text { the process involved in } \\
\text { supplying a product to } \\
\text { someone }\end{array}$ \\
\hline TPR3 & Compatible & $\begin{array}{l}\text { The level connected to } \\
\text { ideas or systems that } \\
\text { are compatible can exist } \\
\text { together }\end{array}$ \\
\hline TPR4 & Business partner & $\begin{array}{l}\text { The level connected of } \\
\text { relationships that are } \\
\text { caring for the } \\
\text { development of the } \\
\text { organization together }\end{array}$ \\
\hline TPR5 & Significant & $\begin{array}{l}\text { The level connected to } \\
\text { company relationships }\end{array}$ \\
\hline ITA1 & Adoption & $\begin{array}{l}\text { The level connected to } \\
\text { decide to use or accept } \\
\text { a particular idea, } \\
\text { method or attitude }\end{array}$ \\
\hline
\end{tabular}




\begin{tabular}{|l|l|l|}
\hline Codes & Names & \multicolumn{1}{|c|}{ Definitions } \\
\hline ITA2 & Facilitators & $\begin{array}{l}\text { The level connected to } \\
\text { helps a person or } \\
\text { organization to find a } \\
\text { solution to a problem }\end{array}$ \\
\hline ITA3 & Coefficient & $\begin{array}{l}\text { The level connected of } \\
\text { a number written before } \\
\text { a variable. }\end{array}$ \\
\hline ITA4 & Framework & $\begin{array}{l}\text { The level connected to } \\
\text { a set of principles, ideas } \\
\text { etc that you use when } \\
\text { you are forming your } \\
\text { decisions } \\
\text { judgments }\end{array}$ \\
\hline ITA5 & Adaptation & $\begin{array}{l}\text { The level connected to } \\
\text { the process of changing } \\
\text { something so that it can } \\
\text { be used for a different } \\
\text { purpose }\end{array}$ \\
\hline
\end{tabular}

In terms of model development (Subiyakto et al., 2015), this study will provide two main points, namely, the confidence and validity of the problem. First, the implementation of this research was carried out transparently and clearly, as explained in the research method section. Readers can pay attention to how the authors use the assumption of model readiness development (Parasuraman and Colby, 2015) and adoption (Chatzoglou and Chatzoudes, 2016, Zhu et al., 2006, Tarute and Gatautis, 2014), combine the two models, and adjust variables, indicators, and questions, in terms of the construct of system utilization. This can be noted with certainty that the clarity of the model of the study development process can show the point of confidence for the development of the model. Second, in addition to utilizing assumptions, combinations and processes of adaptation, readers can also pay attention to how questions can be taken upside down referring to indicators, variables, and assumptions. The above variable is defined as the state where the level of readiness and adoption model developed will express it characteristics in terms of assessing IT use among SMEs in Indonesia

In short, it is clear that the transparency of the model development process and the model rationality developed can be two contributions from this research.

Table 4: List of the questionnaire statements

\begin{tabular}{|l|l|}
\hline Codes & \multicolumn{1}{|c|}{ Statements of the questionnaires } \\
\hline OPT1 & $\begin{array}{l}\text { System is free from obstacles, difficulties, and } \\
\text { problems }\end{array}$ \\
\hline OPT2 & $\begin{array}{l}\text { System can be connected success with the } \\
\text { existing system }\end{array}$ \\
\hline
\end{tabular}

\begin{tabular}{|c|c|}
\hline Codes & Statements of the questionnaires \\
\hline OPT3 & System runs in within limited resources \\
\hline OPT4 & System runs in within the maximum output \\
\hline OPT5 & $\begin{array}{l}\text { System can be run in a measurable and } \\
\text { effective manner }\end{array}$ \\
\hline INV1 & System is a problem-solving tool for users \\
\hline INV2 & $\begin{array}{l}\text { System helps users to be free from the } \\
\text { influences }\end{array}$ \\
\hline INV3 & $\begin{array}{l}\text { System supports users for reaching goals in a } \\
\text { difficult condition }\end{array}$ \\
\hline INV4 & System encourages users for reaching goals \\
\hline INV5 & $\begin{array}{l}\text { System supports users to be more successful } \\
\text { than their competitors }\end{array}$ \\
\hline DCF1 & System confuses users in using it \\
\hline DCF2 & System cannot be used simply \\
\hline DCF3 & System cannot be used freely \\
\hline DCF4 & $\begin{array}{l}\text { System is used without full operating system } \\
\text { support }\end{array}$ \\
\hline DCF5 & $\begin{array}{l}\text { System is not in accordance with the } \\
\text { development plan }\end{array}$ \\
\hline ISC1 & $\begin{array}{l}\text { System was not successfully operated in } \\
\text { accordance with its development planning }\end{array}$ \\
\hline ISC2 & $\begin{array}{l}\text { System is in a condition that can cause harm or } \\
\text { danger }\end{array}$ \\
\hline ISC3 & System will make users less in association \\
\hline ISC4 & System makes users not focus on their interests \\
\hline ISC5 & $\begin{array}{l}\text { System is no doubt used for technology } \\
\text { improvement and development }\end{array}$ \\
\hline TEC1 & $\begin{array}{l}\text { Systems and technologies used are easy to } \\
\text { implement }\end{array}$ \\
\hline TEC2 & Ease of using the internet as a work facility \\
\hline TEC3 & $\begin{array}{l}\text { System used in internal supports work } \\
\text { activities }\end{array}$ \\
\hline TEC4 & $\begin{array}{l}\text { System support in the case of correspondence } \\
\text { so as to facilitate work }\end{array}$ \\
\hline TEC5 & $\begin{array}{l}\text { System is the use of tools that are very } \\
\text { supportive in activities }\end{array}$ \\
\hline FSC1 & $\begin{array}{l}\text { System can reach and can be relied upon to } \\
\text { support marketing }\end{array}$ \\
\hline FSC2 & $\begin{array}{l}\text { System is able to maximize work well } \\
\text { according to capacity }\end{array}$ \\
\hline FSC3 & $\begin{array}{l}\text { System is not easy to error if the data capacity } \\
\text { is increasing }\end{array}$ \\
\hline FSC4 & $\begin{array}{l}\text { System is able to be connected to all units so } \\
\text { that the activity goes well }\end{array}$ \\
\hline FSC5 & $\begin{array}{l}\text { System is that the device can work well } \\
\text { despite the transfer of labor }\end{array}$ \\
\hline FSZ1 & $\begin{array}{l}\text { System is capable of having resources and can } \\
\text { facilitate adoption }\end{array}$ \\
\hline FSZ2 & $\begin{array}{l}\text { System is what can increase the level of } \\
\text { economy and large income }\end{array}$ \\
\hline FSZ3 & $\begin{array}{l}\text { System is something that can bear the risk in } \\
\text { the initial stages of business }\end{array}$ \\
\hline FSZ4 & $\begin{array}{l}\text { System is able to create a model by putting } \\
\text { forward results in accordance with the number } \\
\text { of employees }\end{array}$ \\
\hline FSZ5 & $\begin{array}{l}\text { System is able to adopt technology with } \\
\text { trading partners so that it can be integrated }\end{array}$ \\
\hline
\end{tabular}




\begin{tabular}{|c|c|}
\hline Codes & Statements of the questionnaires \\
\hline CRD1 & $\begin{array}{l}\text { System is able to connect consumers with } \\
\text { existing technology }\end{array}$ \\
\hline CRD2 & $\begin{array}{l}\text { System is what can translate technological } \\
\text { innovation into a profit }\end{array}$ \\
\hline CRD3 & $\begin{array}{l}\text { System is the readiness of consumers for } \\
\text { technology penetration }\end{array}$ \\
\hline CRD4 & $\begin{array}{l}\text { System is to provide improvements to the } \\
\text { technological process developed }\end{array}$ \\
\hline CRD5 & $\begin{array}{l}\text { System is the development in the field of } \\
\text { facilities to facilitate consumers in accessing } \\
\text { technology }\end{array}$ \\
\hline CPR1 & $\begin{array}{l}\text { System is capable of changing competition } \\
\text { rules so that they are more competitive in } \\
\text { competition }\end{array}$ \\
\hline CPR2 & $\begin{array}{l}\text { System is capable of utilizing new ways of } \\
\text { competitive competition }\end{array}$ \\
\hline CPR3 & $\begin{array}{l}\text { System is what can affect the structure of the } \\
\text { industry to be more efficient }\end{array}$ \\
\hline CPR4 & $\begin{array}{l}\text { System is to provide new means to increase } \\
\text { competition through technological } \\
\text { developments }\end{array}$ \\
\hline CPR5 & $\begin{array}{l}\text { System is able to facilitate customers so that } \\
\text { they can increase company profits }\end{array}$ \\
\hline TPR1 & $\begin{array}{l}\text { System is one that requires tighter integration } \\
\text { with customers and suppliers }\end{array}$ \\
\hline TPR2 & $\begin{array}{l}\text { System is that which facilitates the supply } \\
\text { chain in the company }\end{array}$ \\
\hline TPR3 & $\begin{array}{l}\text { System is able to produce data analysis } \\
\text { properly so that decisions taken are correct and } \\
\text { correct }\end{array}$ \\
\hline TPR4 & $\begin{array}{l}\text { System is able to connect all trading partners } \\
\text { by adopting a compatible electronic trading } \\
\text { system }\end{array}$ \\
\hline TPR5 & $\begin{array}{l}\text { System is able to provide Internet-enabled } \\
\text { services for each other }\end{array}$ \\
\hline ITA1 & $\begin{array}{l}\text { System is the development of technology so } \\
\text { that it can follow the method that has been } \\
\text { used }\end{array}$ \\
\hline ITA2 & $\begin{array}{l}\text { System is technology development that can } \\
\text { solve problems based on available data }\end{array}$ \\
\hline ITA3 & $\begin{array}{l}\text { System is able to repair and read customer } \\
\text { numerical data based on technology readiness }\end{array}$ \\
\hline ITA4 & $\begin{array}{l}\text { System is capable of solving problems and } \\
\text { providing ideas for technological development } \\
\text { and decision making }\end{array}$ \\
\hline ITA5 & $\begin{array}{l}\text { System is designed according to the needs and } \\
\text { development of the company }\end{array}$ \\
\hline
\end{tabular}

\section{CONCLUSIONS}

This study will improve understanding of how the link between readiness and IT adoption factors in terms of development in SMEs and how to integrate readiness models and adoption IT models in terms of system use and development. The authors propose a combination model by integrating four readiness model variables and six variables from the adoption IT model, in terms of SME development. In addition to the process of developing clarity, a coherent relationship between models, variables, indicators, and questions from each indicator is also shown by the author. In regard to the limitations of the study around the understanding, assumptions, and perspective issues of the author; In addition to the limitations recommended to be a consideration point for future work, the proposed model and its instruments can also be recommended to proceed to the examination and development stage.

\section{REFERENCES}

Republik Indonesia Undang-UndangNomor 17 Tahun 2007 Tentang Rencana Pembangunan Jangka Panjang Nasional Tahun 2005-2025.

2011. Tempo 2014 Baru 40 Persen UKM Manfaatkan Teknolog iInformasi Retrieved at November 1, 2017 from https://bisnis.tempo.co/read/564637/baru-40persen-ukm-manfaatkan-teknologiinformasi.

A. PARASURAMAN, C. L. C. 2014. The Influence of Technology Readiness Index in Entrepreneurial Orientation A Study with Brazilian Entrepreneurs in the United States of America.pdf. Journal of Service Research 17.

ABDULLAH, M. A., MANAN, A. \& KHADIJAH, S. 2011. Small and Medium Enterprises and Their Financing Patterns: Evidence from Malaysia. Journal of Economic Cooperation \& Development, 32.

ANFARA JR, V. A. \& MERTZ, N. T. 2014. Theoretical frameworks in qualitative research, Sage publications.

BELOUT, A. \& GAUVREAU, C. 2004. Factors influencing project success: the impact of human resource management. International journal of project management, 22, 1-11.

CHATZOGLOU, P. \& CHATZOUDES, D. 2016. Factors affecting e-business adoption in SMEs: an empirical research. Journal of Enterprise Information Management, 29, 327-358.

COLBY, C. L. 2016. Techno-Ready Marketing of eServices: Customer Beliefs About Technology and the Implications for Marketing e-Services. EService: New Directions in Theory and Practice. Routledge.

DAVIS, W. S. \& YEN, D. C. 1998. The information system consultant's handbook: Systems analysis and design, CRC press.

EGGERS, F., KRAUS, S., HUGHES, M., LARAWAY, S. \& SNYCERSKI, S. 2013. Implications of customer and entrepreneurial orientations for SME growth. Management Decision, 51, 524-546. 
FATHIAN, M., AKHAVAN, P. \& HOORALI, M. 2008. E-readiness assessment of non-profit ICT SMEs in a developing country: The case of Iran. Technovation $28,578-590$

FILSER, M. \& EGGERS, F. 2014. Entrepreneurial orientation and firm performance: A comparative study of Austria, Liechtenstein and Switzerland. South African Journal of Business Management, 45, 55-65.

GANGWAR, H., DATE, H. \& RAOOT, A. 2014. Review on IT adoption: insights from recent technologies. Journal of Enterprise Information Management, 27, 488-502.

HANCLOVA, J., ROZEHNAL, P., MINISTR, J. \& TVRDIKOVA, M. 2015. The determinants of IT adoption in SMEs in the Czech-Polish border areas. Information Technology for Development, 21, 426444.

HARINDRANATH, G., DYERSON, R. \& BARNES, D 2008. ICT adoption and use in UK SMEs: a failure of initiatives? Electronic journal of information systems evaluation, 11.

LUCCHETTI, R. \& STERLACCHINI, A. 2004. The adoption of ICT among SMEs: evidence from an Italian survey. Small Business Economics, 23, 151168.

NUGROHO, M. A. 2015. Impact of government support and competitor pressure on the readiness of SMEs in Indonesia in adopting the information technology. Procedia Computer Science, 72, 102-111.

PARASURAMAN, A. 2000. Technology Readiness Index (TRI) a multiple-item scale to measure readiness to embrace new technologies. Journal of service research, 2, 307-320.
PARASURAMAN, A. \& COLBY, C. L. 2015. An updated and streamlined technology readiness index: TRI 2.0. Journal of service research, 18, 59-74.

ROJAS-MÉNDEZ, J. I., PARASURAMAN, A. \& PAPADOPOULOS, N. 2017. Demographics, attitudes, and technology readiness: A cross-cultural analysis and model validation. Marketing Intelligence \& Planning, 35, 18-39.

SHAH ALAM, S., ALI, M. Y. \& MOHD. JANI, M. F. 2011. An empirical study of factors affecting electronic commerce adoption among SMEs in Malaysia. Journal of business economics and management, 12, 375-399.

SUBIYAKTO, A. 2017. Development of The Readiness and Success Model for Assessing the Information System Integration. International Conference on Science and Technology (ICOSAT) 2017. Jakarta.

SUBIYAKTO, A. \& AHLAN, A. R. 2014 Implementation of Input-Process-Output Model for Measuring Information System Project Success. TELKOMNIKA Indonesian Journal of Electrical Engineering, 12, 5603-5612.

SUBIYAKTO, A., AHLAN, A. R., PUTRA, S. J. \& KARTIWI, M. 2015. Validation of Information System Project Success Model. SAGE Open, 5, 1-14.

TARUTE, A. \& GATAUTIS, R. 2014. ICT impact on SMEs performance. Procedia-Social and Behavioral Sciences, 110, 1218-1225.

ZHU, K., KRAEMER, K. L. \& XU, S. 2006. The process of innovation assimilation by firms in different countries: a technology diffusion perspective on e-business. Management science, 52, $1557-1576$ 